\title{
Effect of chemical preservatives on the shelf life of tomato juice
}

\author{
Fahriha Nur-A Kabir1*, Tajnuba Sharmin ${ }^{1}$, Neaj Ahmed ${ }^{2}$, Md. Shohel Rana Palleb ${ }^{3}$ \& Nilam Debi Bristi ${ }^{4}$ \\ ${ }^{1}$ Lecturer North Pacific International University of Bangladesh, Manikgonj-1800 \\ ${ }^{2}$ B. Sc in Food and Process Engineering, Hajee Mohammad Danesh Science and Technology University 5200 \\ ${ }^{3}$ M.S in Agricultural Extension Education Bangladesh Agricultural University Mymensingh-2202 \\ ${ }^{4}$ M.S in Agricultural Chemistry Hajee Mohammad Danesh Science and Technology University - 5200 \\ *Corresponding Author Email: tisha0025@gmail.com
}

\section{DOI: 10.2478/acmy-2019-0006}

\begin{abstract}
:
This research conducted with the fully fresh, ripe and sound tomato (Lycopersicon esculentum Mill.) was collected then washed, peeled, seeds removed and transferred to the juice extractor. Sugar, preservatives were added to the extracted filtrated juice. Then the juice was heated, cooled and bottled for preservation. Tomato juice was prepared with three different treatments. Among the three treatments T1, T2 and T3 sample were prepared with no preservative, Na-benzoate preservative and potassium meta-bisulphite (KMS) preservative respectively. The organoleptic observation of this tomato juice was studied for 60 days storage period. Chemical analysis and sensory tests were carried out during the 30 days at an interval of 15 days to assess the effect of chemical additives on the shelf life of tomato juice. Negligible Change in chemical constituents except vitamin C was observed in the prepared juice throughout the 30 days storage period. Color was gradually faded and slightly off flavor develops at the end of the storage periods. The treatment T2 secured highest score for color, flavor, taste and overall acceptability and ranked as "Like very much" by a taste testing panel. Tomato juice prepared with no preservative (T1) spoiled after 45 days storage and juice prepared with KMS preservative (T3) spoiled after 60 days storage. Total number of viable bacteria was highest in tomato juice treated with no preservative (T1) and KMS preservative (T3). Tomato juice with Na-benzoate preservative (T2) contained least viable bacteria which was better than T1 and T3 sample. Considering all the parameters, Na-benzoate tends to be better additives than potassium metabisulphite (KMS) for preservation of tomato juice.
\end{abstract}

Keywords: Tomato, Preservative, Sensory Analysis, KMS, Storage.

\subsection{Introduction:}

In modern day diets, vegetable juice places a very important role in many cities all over the world. It became important in recent years due to overall increase in natural juice consumption as an alternative to the traditional caffeine containing beverages such as coffee, tea, carbonated soft drinks. Making juice is an easy way to add more vegetable to any diet. Consuming fruits and vegetables promote health, energy, quality of life. A diet that is rich in fruits and vegetables has been associated with protection against cardiovascular disease [8] and several common cancers [34]. Fruits and vegetables juice have significant improved blood profile in people affected by hyper-cholesterolemia as well as promote detoxification of human body [10].

Tomato is one of the most popular and demanding vegetables because of its vitamin and valuable nutrients content. Tomato (Lycopersicon esculentum) belongs to the family Solanaceae. Its center of origin is presumed to be in the present state of Mexico [15]. It is believed that the tomato was introduced Indian subcontinent during the British resume. Now days in Bangladesh, good amount of tomato grows. In 2016-17, 389 thousand metric tons tomato produced in Bangladesh (BBS, 2017).

Tomato is highly perishable vegetables and rapidly deteriorates after ripening. Due to lack of processing, storage and transport facilities, 35 percent of the total production of fruit and vegetables are spoiled and lost after harvest [1]. In season, price and demand of tomatoes are very low which causes economic loss for the farmer. On the other hand, during end period of harvesting season the tomato price becomes 2 to 3 times higher. Hence the short preservation like making tomato juice, tomato puree, cocktail, paste, ketchup, sauce, jelly, soups, powder and Tomato chutneys etc. will help the grower by reducing economic loss.

Tomato juice is a ready to drink tomato products. The quality attributes (flavor, color, consistency and nutritive value) of tomato juice are influenced by variety, climate, cultural practice, harvesting procedure, degree of ripeness, length of storage before processing, washing, sorting and steps of the processing procedure. The effects of length and temperature of storage period and the relationship of oxygen, light, sugar, $\mathrm{pH}$ and ascorbic acid change in color of juices. Storage temperature and oxygen were the most specific for color injury of both juices and pigments. Exposure to light caused little deterioration in color. Tomato juice is also susceptible to microbial spoilage and readily spoiled by the bacterial growth and activities. Considering all the above factors an attempt was made to prepare the tomato juice from different chemical preservatives namely Potassium meta-bisulphite, Na-Benzoate and to study their effect on the shelf life to fulfill the following specific objectives;

1. To study the proximate composition, shelf life and sensory attributes of prepared tomato juice.

2. To examine the effect of chemical preservatives namely Potassium meta-bisulphite, Na-Benzoate on the physiochemical characteristics of tomato juice.

\subsection{Materials and Methods}

This Research was performed in the laboratory of the Department of Food Processing and Preservation and some analysis were conducted in Agriculturalchemistry laboratory, Hajee Mohammad Danesh Science and Technology University, Dinajpur. The mature tomatoes, sugar preservatives and other ingredients were collected from local market of Dinajpur. Chemicals and reagents in the study were used from laboratory stockanalytically graded with the highest purity.

\subsection{Methodology}

Tomato Juice was prepared according to the method by [25].

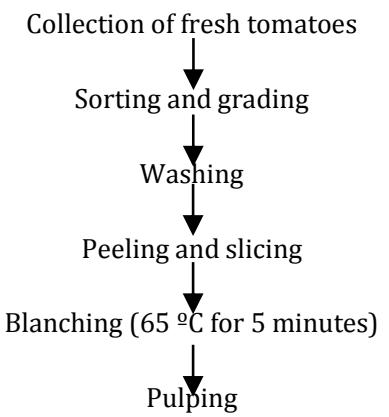

Sugar, salt, thickening agent, preservatives

Homogenization or mixing 
Pasteurization $\left(75^{\circ} \mathrm{C}\right.$ for $2-3$ minutes)

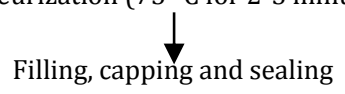

Figure 1: Schematic illustration of the experimental design

The experiment was examined with three samples which vary with the different preservatives. Basic treatments for preparation of Tomato juice shown in table 1

Table 1 Basic treatment for preparation of tomato juice

\begin{tabular}{|c|c|c|c|}
\hline Ingredient & Sample $\mathrm{T}_{1}$ & Sample $\mathrm{T}_{2}$ & Sample $\mathrm{T}_{3}$ \\
\hline Juice (ml) & $60 \%$ & $60 \%$ & $60 \%$ \\
\hline Water(ml) & $40 \%$ & $40 \%$ & $40 \%$ \\
\hline Sugar(gm) & $20 \%$ & $20 \%$ & $20 \%$ \\
\hline Preservatives(gm) & Control (No preservatives) & $\begin{array}{l}\text { Na-Benzoate } \\
300 \text { ppm }\end{array}$ & $\begin{array}{l}\text { KMS } \\
\quad 300 \mathrm{~m}\end{array}$ \\
\hline
\end{tabular}

\subsection{Proximate analysis}

The proximate analysis of moisture and ash was carried out by using AOAC standard method [6]. Another analysis protein content, Acidity and vitamin C content (Ascorbic acid) were determined by using Kjeldahl method and Rangana method [32] respectively. Total soluble solids (TSS) and pH also determined by using refractometer (Model no. HI 96801, ROMANIA) and pH meter. The minerals content was determined by the method of Pearson [30].

\subsection{Estimation of total sugar}

\subsubsection{Reducing sugar}

The reagents used for the estimation of reducing, non-reducing and total sugar were Fehling's solution (A), Fehling's solution (B), Methylene blue indicator, $45 \%$ Neutral lead acetate solution, $22 \%$ Potassium oxalate solution.

\subsubsection{Standardization of Fehling's solution}

$10 \mathrm{ml}$ of both Fehling's solution A and B were mixed together in a beaker. Standard sugar solution was taken in a burette. $10 \mathrm{ml}$ of mixed solution and $25 \mathrm{ml}$ distilled water taken into $250 \mathrm{ml}$ conical flask and heated on hot plate. When the solution began to boil, three drops of methylene blue indicator solution was added to it. Mixed solution was titrated by standard sugar solution. The end point was indicated by decolorization of the indicator. Fehling's factor was calculated by using the following formula:

$$
\text { Fehling's factor }=\quad \frac{\text { Titre } \times 2.5}{1000}
$$

\subsubsection{Preparation of the sample}

$10 \mathrm{gm}$ of filtered juice and $100 \mathrm{ml}$ of distilled water were mixed in homogenizer and transferred to $250 \mathrm{ml}$ volumetric flask. Then the mixture was neutralized with $0.1 \mathrm{~N} \mathrm{NaOH}$ and $2 \mathrm{ml}$ of lead acetate solution was added and followed to stand for 10 minutes. After that $5 \mathrm{ml}$ potassium oxalate solution was added and made to a volume of $250 \mathrm{ml}$. Then the mixture was filtered and made the dilution.

\subsubsection{Titration for reducing sugar}

$10 \mathrm{ml}$ of mixed Fehling's solution was taken in a conical flask and $25 \mathrm{ml}$ of distilled water was added to it. Purified juice was taken in a burette. Conical flask containing mixed Fehling's solution was added to the flask when boiling started and titrated with solution taken in the burette at the same time. The end point was indicated by decolorization of indicator. Percent reducing sugar was calculated by using the following formula:

$$
\% \text { Reducing sugar }=\quad \frac{\mathrm{I} \times \mathrm{D} \times 100}{\mathrm{~T} \times \mathrm{W} \times 100}
$$

\subsubsection{Non-reducing sugar}

$50 \mathrm{ml}$ purified solution and $50 \mathrm{ml}$ distilled water taken in a conical flask and 5 gm citric acid added to it. Then added sucrose and heated the flask for 10 minutes and finally cooled. $0.1 \mathrm{~N} \mathrm{NaOH}$ solution used to neutralize the sample. The volume was made up to $100 \mathrm{ml}$ with distilled water. For titrated mixed Fehling's solution similar procedure followed as for reducing sugar. Also invert sugar was calculated by using similar procedure as for reducing sugar from which the percent non-reducing sugar is calculated as follows:For titrated mixed Fehling's solution similar procedure followed as for reducing sugar. Invert sugar was calculated by using similar procedure for reducing sugar from which the percent non-reducing sugar is calculated as follows:

$\%$ Non-reducing sugar $=\%$ Invert sugar-\%Reducing sugar

\subsubsection{Estimation of total sugar}

Total sugar can be calculated as follows:

$\%$ Total sugar $=\%$ Reducing sugar $+\%$ Non-reducing sugar.

\subsection{Determination of minerals content in tomato juice}

$1 \mathrm{ml}$ sample with $15 \mathrm{ml}$ of diacid mixture (2:1) $(\mathrm{HNO} \mathrm{HClO}$ ) was taken in a beaker and boiled until the solution become clear. Cooled and made the volume in $100 \mathrm{ml}$.

\subsubsection{Estimation of calcium}

$5 \mathrm{ml}$ solution mixed with $20-25 \mathrm{ml}$ hot distilled water. Added 10 drops of each solution of Potassium pherocyanite, OH- amine, hydrochloride, triethanolamine and $5 \mathrm{ml}$ of $\mathrm{NaOH}$ buffer (10\%) and 5-6 drops calcon indicator. test sample was titrated against EDTA (0.01M) solution from a burette until color changed from pink to blue.

$1 \mathrm{ml} 1 \mathrm{M} \mathrm{Na} 2-\mathrm{EDTA}=40.08 \mathrm{mg} \mathrm{Ca}$

\subsubsection{Estimation of magnesium}

$5 \mathrm{ml}$ solution mixed with $20-25 \mathrm{ml}$ hot distilled water. Then 10 drops of each solution of Potassium pherocyanite, OH- amine hydrochloride, triethanolamine, Na tungstate and $5 \mathrm{ml}$ ammonium buffer and 5-6 drops EBT (Erriochrome Black-T) was added. Test sample was titrated against EDTA 
$(0.01 \mathrm{M})$ solution from a burette until pink color completely turned to pure blue color.

$1 \mathrm{ml} 1 \mathrm{M} \mathrm{Na}_{2}$-EDTA=24.305 $\mathrm{mg}$ of Mg

\subsubsection{Estimation of Potassium}

Exactly $1.907 \mathrm{~g} \mathrm{KCl}$ and 300-400 ml distilled water was taken in a $1000 \mathrm{ml}$ volumetric and shake to dissolve. Then the volume made up to the mark with distilled water. Concentration of that solution is made $100 \mathrm{ppm}$ of potassium. $5 \mathrm{ml}, 10 \mathrm{ml}, 15 \mathrm{ml}, 20 \mathrm{ml}, 25 \mathrm{ml}, 30 \mathrm{ml}, 40 \mathrm{ml}, 50 \mathrm{ml}$ and $60 \mathrm{ml}$ of $100 \mathrm{ppm} \mathrm{K}$ solution was taken in several $100 \mathrm{ml}$ volumetric flask and made volume up to the mark with distilled water.Finally, in Flame Emission Photometer showed the reading directly for unknown solution.

\subsection{Microbiological test}

\subsubsection{Determination of total viable bacteria}

Total viable count of microorganism present in the sample was followed according to the method "Recommended method for the microbiological examination of food" method [5].

\subsubsection{Preparation of media}

Peptone2.5 gm, Agar9.0gm, Beef extract1.5 gm, Sodium chloride ( $\mathrm{NaCl}) 1.0 \mathrm{gm}$, Distilled water500 ml taken in a conical flask and heated for proper mixing. During heating the mixture was rotted with a glass rod. After proper mixing, the head of the flask was blocked with cotton plug andaluminum foil. Then the conical flask with media was placed in autoclave for sterilization (Temperature: $121^{\circ} \mathrm{C}$, Pressure: $15 \mathrm{Ib} / \mathrm{inch}^{2}$ and time: 15 mins.).

\subsubsection{Preparation of dilution blank}

In order to dilute the sample consecutively $1 \mathrm{ml}$ of the sample was diluted stepwise through a series of tubes containing $9 \mathrm{ml}$ of distilled water. At first $9 \mathrm{ml}$ of the distilled water was taken in a sterile test tubes and then $1 \mathrm{ml}$ of the original sample (juice) was taken to the first test-tube with a sterile pipette. Water with the sample was vigorously shaken for homogenous distribution of the bacterial population in the solution. This tube was denoted as " $A$ ". From the tube "F-1" another $1 \mathrm{ml}$ aliquot was transferred to the second tube and this tube was denoted as "F-2". In this way "F-3", "F-4", "F-5", "F-6" was prepared until the desired dilution is achieved. Now the tube "F-1" has got the dilution $10^{-1}, 10^{-2}, 10^{-3}, 10^{-4}, 10^{-5}, 10^{-6}$ respectively.

The dilutions were as follows:

\begin{tabular}{|l|l|ll|}
\hline Tube No. & Dilution & \multicolumn{2}{|l|}{ Volume of original fluid per mi } \\
\hline $\mathbf{1}$ & $1 / 10$ & 0.1 & or $10^{-1}$ \\
\hline $\mathbf{2}$ & $1 / 100$ & 0.01 & or $10^{-2}$ \\
\hline $\mathbf{3}$ & $1 / 1,000$ & 0.001 & or $10^{-3}$ \\
\hline $\mathbf{4}$ & $1 / 10,000$ & 0.0001 & or $10^{-4}$ \\
\hline $\mathbf{5}$ & $1 / 100,000$ & 0.00001 & or $10^{-5}$ \\
\hline $\mathbf{6}$ & $1 / 1,000,000$ & $0.000001 \quad$ or $10^{-6}$ \\
\hline
\end{tabular}

\subsubsection{Procedure of plating}

Now from the test-tube "F-1", $1 \mathrm{ml}$ of the sample solution was taken in a sterile Petridis containing $9 \mathrm{ml}$ of agar medium. The agar with bacterial sample was mixed by rotating the Petridis. This Petridis was marked as "A". In this way "B", “C", "D", "E", " $F$ " marked Petri dishes were prepared from the tubes " $F-2$ ", "F-3", "F-4"," F-5" and "F-6" respectively. Then these Petri dishes were placed on a level surface for few minutes for solidifying the agar medium.

\subsubsection{Incubation and colony count}

After solidification Petridis were placed in the incubator at $36-37^{\circ} \mathrm{C}$ for $20-24$ hours, the over loaded Petri dishes were avoided and the Petri dishes containing countable colony were selected. Colonies were counted with the aid of a magnifying glass and finally the total number of bacteria per gram of sample was calculated by the following equation:

Colony count $($ per $\mathrm{ml})=$ Number of colonies (per plate) $\times$ Reciprocal of the dilution.

\subsection{Sensory evaluation of tomato juice}

The sensory evaluation of tomato juice was evaluated for color, flavor, taste, texture and overall acceptability parameters by 20 tasters.For the evaluation of tomato juice were given to 20 panelist and randomly coded sample and asked to rate the given sample a 9 point hedonic scale with ratings of: $9=$ Like extremely, 8 = Like very much, 7 = Like moderately, $6=$ Like slightly, 5 = Neither like or unlike, $4=$ Dislike slightly, $3=$ Dislike moderately, $2=$ Dislike very much, 1 = Dislike extremely. The results were evaluated by Analysis of Variance and Duncan's Multiple Range Test (DMRT) procedures of Statistical Analysis System (SAS, 1985).

\subsection{Studies on storage stability of prepared tomato juice}

Processed tomato juice was store at refrigeration temperature $\left(4^{\circ} \mathrm{C}\right)$ in glass bottle, shelf life of tomato juice was assessed by objective and subjective tests at different time intervals. The moisture content, $\mathrm{pH}$, acidity, TSS, vitamin $\mathrm{C}$, color, flavor, texture and fungal growth were observed initially for 1 month.

\subsection{Statistical analysis}

Data were analyzed using statistical software R (windows version 2.13.1). a single factor analysis of variance was carried out. Significant difference was estimated using Duncan Multiple Range Tests (DMRT). Differences were considered to be significant at $\leq 0.05$.

\subsection{Result and Discussion}

The tomato juice is perishable and subjected to quick deterioration during storage. The present study was undertaken to assess the effect of different preservatives on the tomato juice during storage at refrigeration temperature.

\subsection{Proximate composition of tomato juice}

The juice samples were analyzed for physical (moisture, $\mathrm{pH}$, acidity, total sugar and total soluble solid), chemical (protein, ash, vitamin C) and mineral 
(calcium, magnesium, potassium) properties. The approximate composition of tomato juice per $100 \mathrm{~g}$ showed in the Table 2.

Table 2 Approximate composition of tomato juice per $100 \mathrm{~g}$

$\begin{array}{lll}\text { Components } & \text { Fresh Pulp } & \text { Processed Juice } \\ \text { Moisture } & 93.50 & 81.28 \\ \text { Ash } & 0.28 & 0.248 \\ \text { Acidity } & 0.424 & 0.312 \\ \text { pH } & 3.85 & 4.69 \\ \text { Vitamin C } & 16.75 & 12.25 \\ \text { Total soluble solid } & 2.00 & 13.00 \\ \text { total sugar } & 3.65 & 8.00\end{array}$

\subsection{Chemical analysis for tomato juice}

Physical properties of tomato juice immediate after preparation shown in table 3

Table 3 Physical properties of tomato juice immediate after preparation i.e., $0^{\text {th }}$ day

\begin{tabular}{|l|l|l|l|l|l|l|}
\hline Sample & Treatment & Moisture (\%) & pH & TSS (\%) & Acidity (\%) & Total sugar (\%) \\
\hline $\mathrm{T}_{1}$ & Control & $81.28^{\mathrm{c}}$ & $4.69^{\mathrm{a}}$ & $13.13^{\mathrm{a}}$ & $0.248^{\mathrm{a}}$ & $6.44^{\mathrm{c}}$ \\
\hline $\mathrm{T}_{2}$ & Na-benzoate & $83.15^{\mathrm{b}}$ & $4.68^{\mathrm{a}}$ & $13.46^{\mathrm{a}}$ & $0.31^{\mathrm{a}}$ & $8.06^{\mathrm{b}}$ \\
\hline $\mathrm{T}_{3}$ & KMS & $83.22^{\mathrm{a}}$ & $4.69^{\mathrm{a}}$ & $13.22^{\mathrm{a}}$ & $0.255^{\mathrm{a}}$ & $9.66^{\mathrm{a}}$ \\
\hline LSD & & 0.063 & 0.089 & 0.641 & 0.06 & 1.28 \\
\hline CV \% & & 0.02 & 0.96 & 2.42 & 10.67 & 0.43 \\
\hline
\end{tabular}

$a, b, c$ means bearing the same superscript within the column do not differ significantly ( $p \geq 0.05)$.

The prepared tomato juice was tested for chemical composition immediately after preparation, i.e. $0^{\text {th }}$ day. The moisture content of samples $\mathrm{T}_{1}, \mathrm{~T}_{2}$ and $\mathrm{T}_{3}$ were $81.28 \%, 83.15 \%, 83.22 \%$, respectively. The highest amount of moisture content in samples $\mathrm{T}_{3}$ was treated with KMS compare to other samples. This result is close to tomato juice $\left(86.32 \%\right.$ moisture) obtained by Jannat et al., (2016). There was significant different between the sample $\mathrm{T}_{1}, \mathrm{~T}_{2}$ and $\mathrm{T}_{3}$. The moisture content was found for tomato juice reported ranged from $93.8 \%$ to $94.1 \%$ depending on the varieties [24]. The small variation may be due to technical error in measuring procedure and the difference is statistically insignificant. The high moisture content of these fruit juices gives great impact on energy density (amount of energy in a given weight of food (kcal/g)) as water adds substantial weight to the food without adding energy and this may give the consumers a better satiety without increase their energy intake [28].

The $\mathrm{pH}$ of sample $\mathrm{T}_{1}, \mathrm{~T}_{2}$ and $\mathrm{T}_{3}$ were 4.69, 4.68 and 4.69, respectively. The highest amount of $\mathrm{pH}$ in sample $\mathrm{T}_{1}$ was treated with no preservatives other than two samples. There was no significant difference between the samples. Several researchers have reported fruit and vegetable juices with different $\mathrm{pH}$ values. Tomato juice has been reported to contain a pH range of $3.7-4.5$ by Frazier and Westhoff (1995). Akusu et a., (2016) found that pineapple juice has a pH value of 3.97. Adubofuor et al., (2010) reported a range of 4.82 - 4.99 for cocktail juices, Ndife et al., (2013) observed a range of 3.23 - 4.08 for different brands of orange juices.

The total soluble solid of sample $\mathrm{T}_{1}, \mathrm{~T}_{2}$ and $\mathrm{T}_{3}$ were $13.13,13.46$ and $13.22^{\circ}$ Brix, respectively. The highest amount of pH in sample $\mathrm{T}_{2}$ was treated with Nabenzoate compare to other two samples. There was no significant difference between the samples.

The acidity of sample $\mathrm{T}_{1}, \mathrm{~T}_{2}$ and $\mathrm{T}_{3}$ were $0.248 \%, 0.31 \%$ and $0.255 \%$, respectively. The highest amount of acidity in sample $\mathrm{T}_{2}$ was treated with Na-benzoate compare to other two samples. There was no significant difference between the samples. The result is similar that is reported by Herna'ndez et al., (2007b) was obtained $0.30 \pm 0.09 \mathrm{~g} / 100$ g acidity.

The total sugar of sample $\mathrm{T}_{1}, \mathrm{~T}_{2}$ and $\mathrm{T}_{3}$ were $6.44 \%, 8.06 \%$ and $9.66 \%$, respectively and showed significant difference in all the samples. Ndife et al., (2013) reported a range of $9.15-14.25 \%$ total sugar for different brands of orange juice. El-Sheikha et al., (2010) reported a Recommended Dietary Allowances (RDA) of $130 \mathrm{~g} /$ day for total sugars, consumption of tomato fruit juice will contribute about $14.88 \%$. Chemical \& mineral properties of tomato juice immediate after preparation was shown in table 4.

Table 4 Chemical \& mineral properties of tomato juice prepared immediate after preparation i.e., $0^{\text {th }}$ day

\begin{tabular}{|l|l|l|l|l|l|l|l|}
\hline Sample & Treatment & $\begin{array}{l}\text { Protein } \\
(\%)\end{array}$ & Ash (\%) & $\begin{array}{l}\text { Vitamin-C mg/100 } \\
\text { g }\end{array}$ & Ca mg/100ml & $\begin{array}{l}\text { Mg } \\
\mathrm{mg} / 100 \mathrm{ml}\end{array}$ & $\begin{array}{l}\mathrm{K} \\
\mathrm{mg} / 100 \mathrm{ml}\end{array}$ \\
\hline $\mathrm{T}_{1}$ & Control & $0.85^{\mathrm{a}}$ & $0.27^{\mathrm{a}}$ & $12.25^{\mathrm{b}}$ & $9.13^{\mathrm{b}}$ & $11.25^{\mathrm{a}}$ & $222.4^{\mathrm{a}}$ \\
\hline $\mathrm{T}_{2}$ & Na-benzoate & $0.84^{\mathrm{a}}$ & $0.27^{\mathrm{a}}$ & $15.62^{\mathrm{a}}$ & $10.08^{\mathrm{a}}$ & $11.80^{\mathrm{a}}$ & $228.8^{\mathrm{a}}$ \\
\hline $\mathrm{T}_{3}$ & KMS & $0.85^{\mathrm{a}}$ & $0.28^{\mathrm{a}}$ & $15.75^{\mathrm{a}}$ & $10.03^{\mathrm{a}}$ & $11.13^{\mathrm{a}}$ & $226.3^{\mathrm{a}}$ \\
\hline LSD & 0.11 & 0.063 & 0.58 & 0.92 & 0.72 & 8.93 \\
\hline CV $\%$ & & 5.95 & 2.31 & 2.00 & 4.64 & 3.15 & 1.98 \\
\hline
\end{tabular}

Protein content of the different concentration of tomato juice was low, ranging from $0.85-0.85 \%$ for samples $\mathrm{T}_{1}$ and $\mathrm{T}_{3}$, respectively (Table 3.3 ). Sample $\mathrm{T}_{3}$ was observed to have higher value compared to other samples and there was no significant difference.

The ash content was observed in sample $\mathrm{T}_{1}(0.27 \%), \mathrm{T}_{2}(0.27 \%), \mathrm{T}_{3}(0.28 \%)$. There was no significant difference between samples $\mathrm{T}_{1}, \mathrm{~T}_{2}$ and $\mathrm{T}_{3}$. Akusu et al., (2016) found the value $0.30 \%$ for tomato juice.

The vitamin $C$ of sample $T_{1}, T_{2}, T_{3}$ were $12.25,15.62,15.75 \mathrm{mg} / 100 \mathrm{~g}$, respectively. The highest amount of vitamin $\mathrm{C}$ in sample $\mathrm{T}_{3}$ was treated with KMS other than two samples. There was significant difference between the samples. Apart from samples $\mathrm{T}_{1}(12.25 \mathrm{mg} / 100 \mathrm{~g})$, there was no significant difference between sample $\mathrm{T}_{2}(15.62 \mathrm{mg} / 100 \mathrm{~g})$ and $\mathrm{T}_{3}(15.75 \mathrm{mg} / 100 \mathrm{~g})$ for vitamin $\mathrm{C}$. The values found in the present study were comparable to the ones reported by Kotkov et al., (2011) (12-17 mg/100 g) and lower than that reported by Ilahy et al., (2011) and Juroszek et al., (2009). 
Calcium content of different concentration of tomato juice has been shown in Table 3.4. Higher calcium value was found in sample $\mathrm{T}_{2}(10.08 \%)$ as compared to sample $\mathrm{T}_{1}(9.13 \%)$ and $\mathrm{T}_{3}(10.03 \%)$. Apart from samples $\mathrm{T}_{1}$, there was no significant difference between sample $\mathrm{T}_{2}(10.08 \mathrm{mg} / 100 \mathrm{ml})$ and $\mathrm{T}_{3}(10.03$ $\mathrm{mg} / 100 \mathrm{ml}$ ) for calcium. Calcium content of different varieties of tomato juice ranged $9.85-12.21 \mathrm{mg} / 100 \mathrm{ml}$ reported by Ensminger et al., (1983).

Magnesium content of the different tomato juice was ranging from $11.25-11.80 \mathrm{mg} / 100 \mathrm{ml}$ for samples $\mathrm{T}_{1}$ and $\mathrm{T}_{2}$, respectively (Table 3.3). Sample $\mathrm{T}_{2}$ was observed to have higher value compared to other samples and there was no significant difference. Watt and Merrill et al., (1963) also found in a lower amount of magnesium in different varieties of tomato.

The highest potassium content was observed in sample $\mathrm{T}_{2}(228.8 \mathrm{mg} / 100 \mathrm{ml})$ and lowest in sample $\mathrm{T}_{1}$ with the value of $222.4 \mathrm{mg} / 100 \mathrm{ml}$. There was no significant difference between samples $\mathrm{T}_{1}, \mathrm{~T}_{2}$ and $\mathrm{T}_{3}$.

\subsection{Effect of chemical preservatives on the prepared tomato juice at various storage periods}

\subsubsection{Effect of chemical preservatives on moisture content}

The Moisture content of chemically preserved tomato juice ranged from $81.28 \%-83.22 \%$. Juice prepared with Na-benzoate ( $\left.\mathrm{T}_{2}\right)$ contained $83.15 \%$

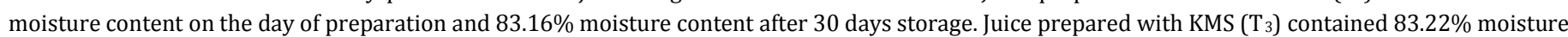
content on the day of preparation and $83.16 \%$ moisture content after 30 days storage shown in Figure 2. Juice prepared with no preservatives $\left(\mathrm{T}_{1}\right)$ contained 81.28\% moisture content on the day of preparation and $81.26 \%$ moisture content after 30 days storage. After 30 days of storage, moisture content reduced very small amount in juice prepare with Na-benzoate ( $\mathrm{T}_{2}$ sample) and Potassium meta-bisulphite $\left(\mathrm{T}_{3}\right.$ sample). But in case of Control samples, moisture content slightly reduced after 30 days storage. Moisture content remained more or less same through 30 days storage.

\section{- Control $\square$ Na-Benzoet $\square$ KMS}

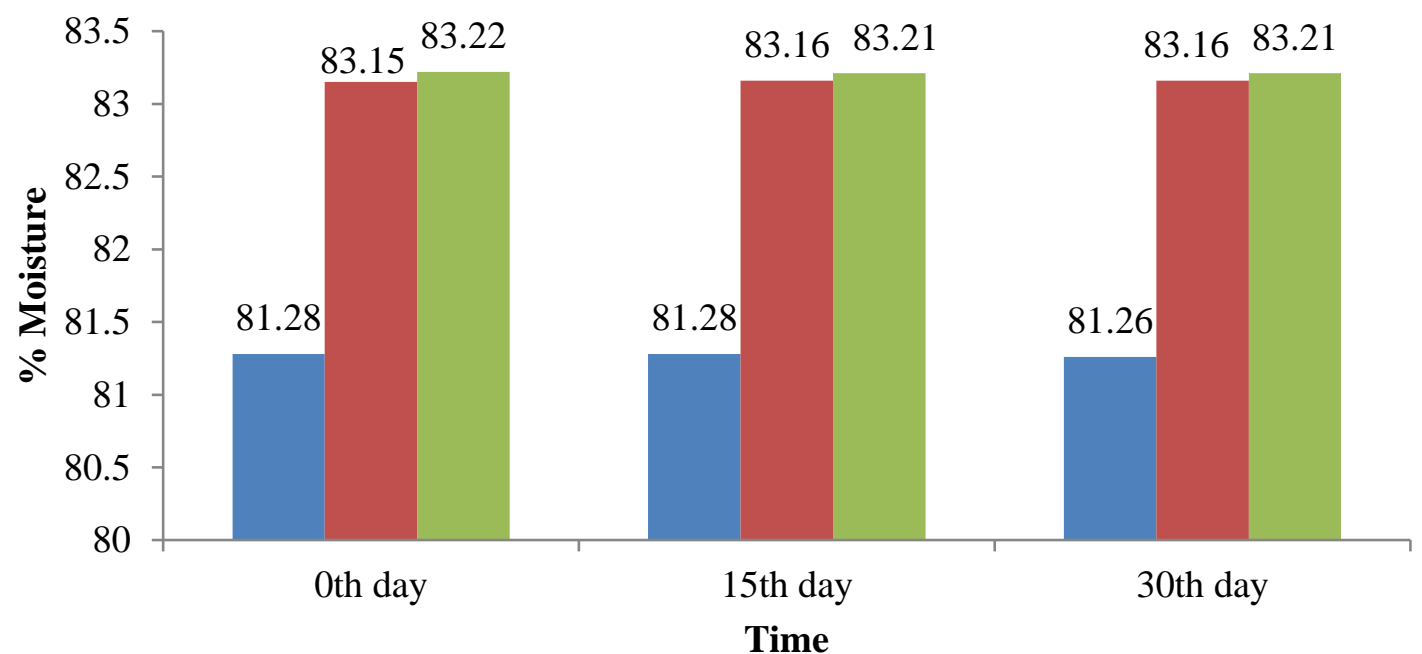

Figure 2: Effect of chemical preservatives on moisture content

\subsubsection{Effect of chemical preservatives on $\mathrm{pH}$}

The $\mathrm{pH}$ of the examined tomato juices ranged from 4.43 to 4.69 shown in Figure 3. The $\mathrm{pH}$ decreased as the number of days of storage increased, indicating acidity in tomato juices. The use of sodium benzoate, potassium meta-bisulphite as preservatives significantly influenced the $\mathrm{pH}$ of tomato juice. The $\mathrm{pH}$ of samples was decreased after 15 days storage shown in figure 2. However, after 30 days storage, the $\mathrm{pH}$ of tomato juice preserved using potassium metabisulphite, Na-benzoate and the control sample slightly decreased. The slight reduction in $\mathrm{pH}$, observed in sample $\mathrm{T}_{1}, \mathrm{~T}_{2}$ and $\mathrm{T}_{3}$ due to the biochemical degradation of sugars by colonizing microorganisms resulting in the production of acids. The work is similar to Shahnawaz et al., (2013), Makanjuola et al., (2013) and Ajibola et al., (2009). They reported a decrease in pH with increasing storage periods in fruit juices. Mishra et al., (2012) reported that pH values decreased from 4.02 to 3.41 in amla-grape blend juice during storage. Hosssain et al., (2011) found that pH decreased from 4.30 to 2.90 in apples and apricot blend juice during storage. High acid and low $\mathrm{pH}$ may be due to production of acetic acid and lactic acid during storage. 


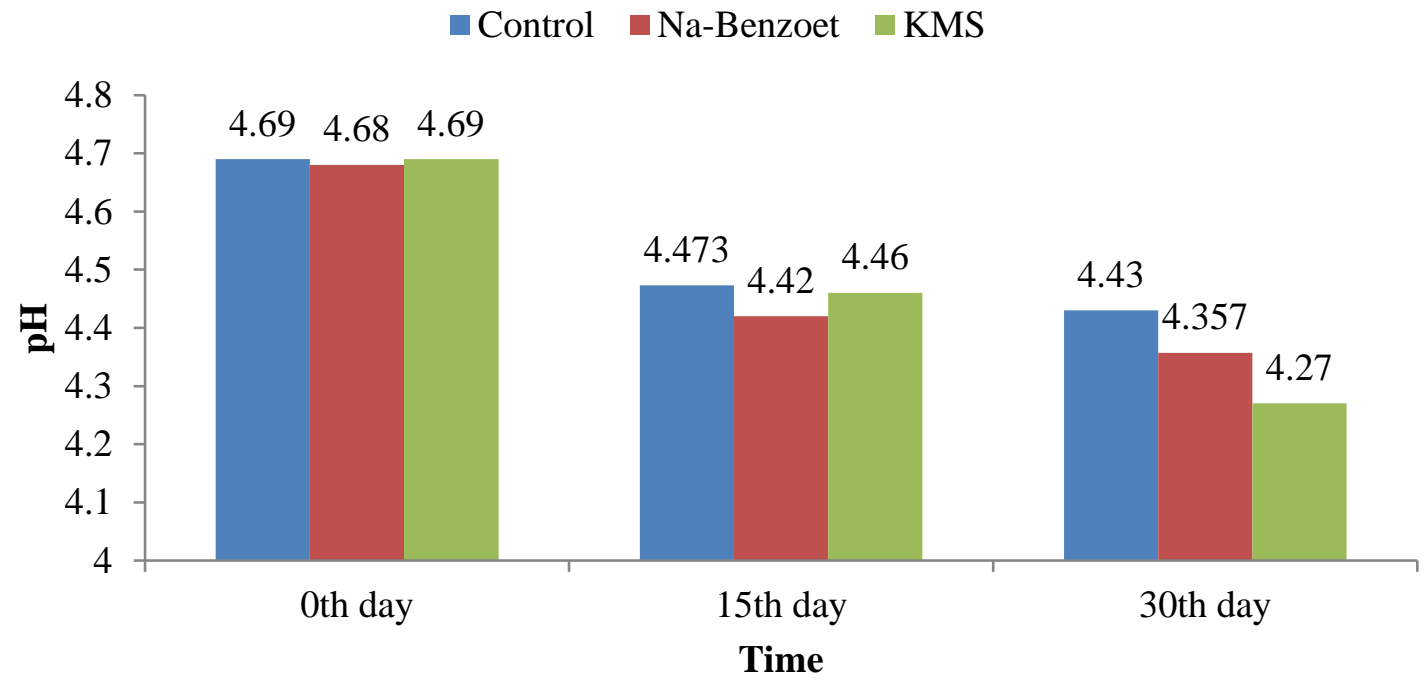

Figure 3: Effect of chemical preservatives on $\mathrm{pH}$

\subsubsection{Effect of chemical preservatives on TSS}

The total soluble solids of chemically preserved tomato juice ranged from $12.16-13.13{ }^{\circ}$ Brix. The total soluble solids of samples $\mathrm{T}_{1}, \mathrm{~T}_{2}$ and $\mathrm{T}_{3}$ were $13.13^{\circ} \mathrm{Brix}, 13.46^{\circ} \mathrm{Brix}, 13.22^{\circ} \mathrm{Brix}$ in the preparation day storage. After 30 days storage the total soluble solids of samples $\mathrm{T}_{1}, \mathrm{~T}_{2}$ and $\mathrm{T}_{3}$ reduced to respectively $12.16^{\circ} \mathrm{Brix}, 13.05^{\circ} \mathrm{Brix}$ and $12.62^{\circ}$ Brix shown in figure 4 . After 30 days of storage the total soluble solids were the lowest in the control juice $\left(12.16^{\circ} \mathrm{Brix}\right)$ while the total soluble solids were the highest in the juice preserved with Na-Benzoate $\mathrm{T}_{2}$ sample $\left(13.05^{\circ} \mathrm{Brix}\right)$. These results are in agreement with the results obtained by Zeb et al., (2009) during preservation of grape juice stored at room temperature for one month preserved with sodium benzoate and potassium sorbate. Similar results were also obtained by Hussain et al., (2011) who worked on the storage of apple and apricot blended juice at refrigeration temperature for three months. Increase in soluble solids may be due to break down of polysaccharides into monosaccharide and oligosaccharides while decrease may be due to fermentation of sugars into ethyl alcohol, carbon dioxide and water [11].

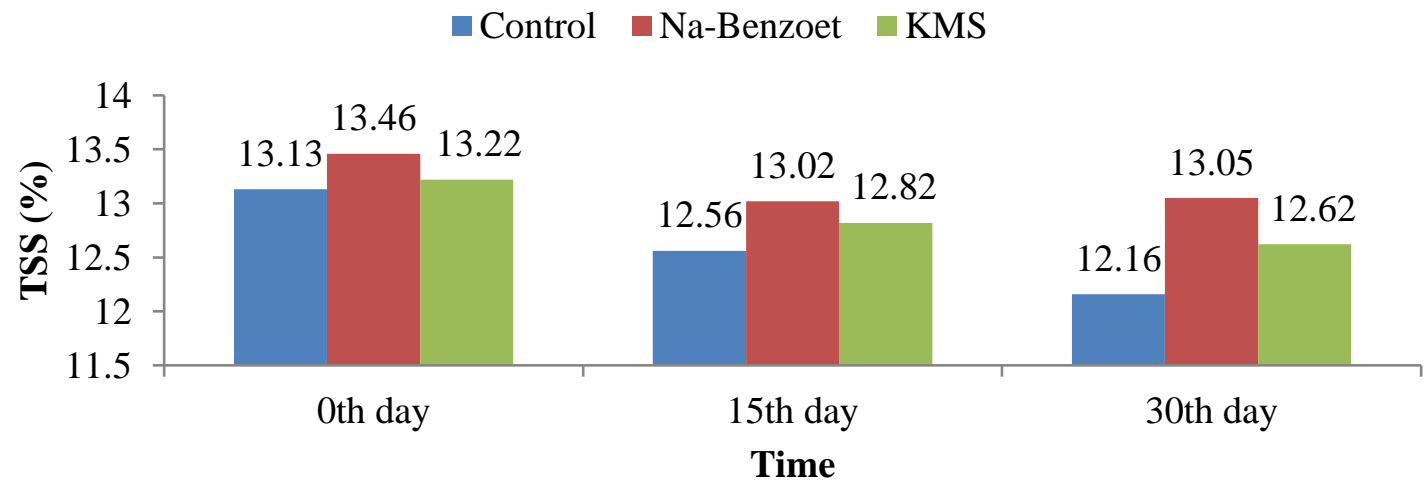

Figure 4: Effect of chemical preservatives on TSS

\subsubsection{Effect of chemical preservatives on acidity}

The total titrable acidity (TTA) of tomato juice ranged from $0.248-0.31 \%$. The TTA slightly increased as number of days of storage increased and was the highest in the potassium meta-bisulphite preserved sample and the lowest in control sample. The increase in the TTA of the juices might be due to fermentation activities by colonizing microorganisms [29]. In the preparation day, the total solids of samples $\mathrm{T}_{1}, \mathrm{~T}_{2}$ and $\mathrm{T}_{3}$ were respectively $0.248 \%, 0.31 \%$, $0.255 \%$. After 30 days storage the total solids of samples $\mathrm{T}_{1}, \mathrm{~T}_{2}$ and $\mathrm{T}_{3}$ were slightly increased respectively to $0.273 \%, 0.315 \%, 0.312 \%$ shown in Figure 5 . This might be due to the high solubility index of sodium meta-bisulphite and sodium benzoate in water. This is in conformity with the report of Kaur and Aggarwal (2014) who evaluated the effect of different chemical preservatives on storage characteristics of bitter gourd. Wadikar et al., (2010) reported that acidity increased from $0.25-0.36 \%$ during storage of cucumber-basil juice. Rahman and Hossain, (2011) found that acidity changed from $0.39 \%$ to $0.51 \%$ in apple and appricot blend juice during storage. 


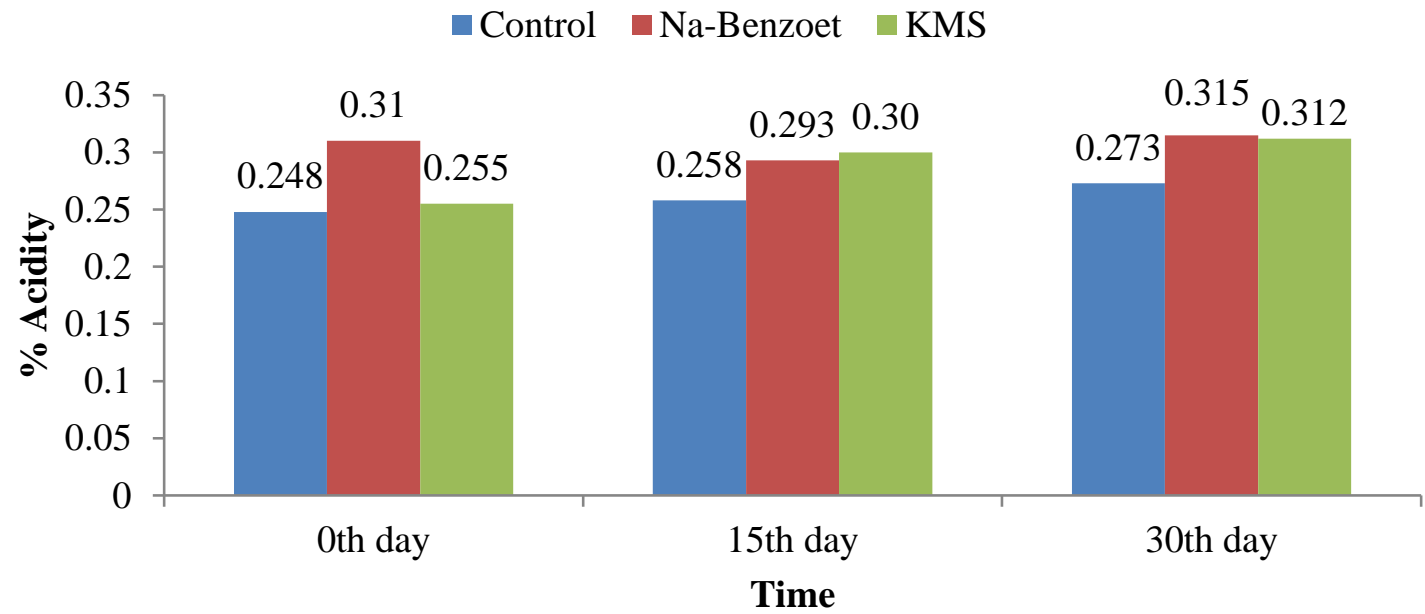

Figure 5: Effect of chemical preservatives on acidity

\subsubsection{Effect of chemical preservatives on vitamin C}

The ascorbic acid (vitamin C) contents of the samples are presented in Figure 6. The vitamin C content of the chemically preserved tomato juice ranged from $15.75-2.6 \mathrm{mg} / 100 \mathrm{~g}$ and decreased with increase in day of storage. This is in support of the report of Akinola et al., (2017) on a juice blend of orange, watermelon, carrot and ginger. After the $30^{\text {th }}$ days of storage, the vitamin C content was the highest in sodium benzoate ( $\left.11.25 \mathrm{mg} / 100 \mathrm{~g}\right)$. In the preparation day, the vitamin $C$ content of samples $\mathrm{T}_{1}, \mathrm{~T}_{2}$ and $\mathrm{T}_{3}$ were $12.25,15.62$ and $15.75 \mathrm{mg} / 100 \mathrm{~g}$ respectively shown in Figure 6 . After 30 days storage the vitamin C of samples $\mathrm{T}_{1}, \mathrm{~T}_{2}$ and $\mathrm{T}_{3}$ were highly decreased to $2.6,11.25$ and $5.033 \mathrm{mg} / 100 \mathrm{~g}$ respectively. The results are in similar with the findings of Zeb et al, (2009) who worked on the preservation of grape juice with sodium benzoate and potassium sorbate, stored at room temperature for one month, they observed decrease in vitamin C content of grape juice. The results of Ayub and Khan (2001) are in agreement with our results, who observed decrease in vitamin C content of pomegranate syrup, preserved under different light conditions and different packaging materials at room temperature for storage period of four months. The losses may be due to oxygen present in the product and headspace of the package. Hussain et al., (2011) found that ascorbic acid changed from 5.67\% to 3.64\% in apple and appricot blend juice during storage. Ascorbic acid changed from 18.38 to $12.90 \mathrm{mg} / 100 \mathrm{ml}$ juice in kinnowanola-ginger blend juice [9].

\section{- Control $\square$ Na-Benzoet $\square$ KMS}

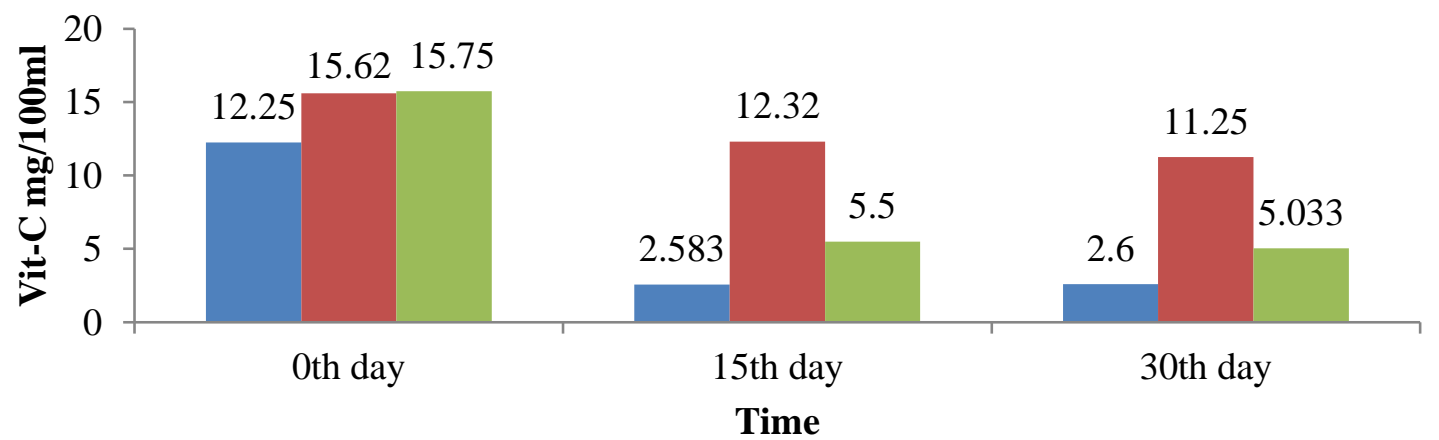

Figure 6: Effect of chemical preservatives on vitamin C

\subsection{Storage studies}

Three treatments of tomato juice were stored at refrigerated temperature $\left(4^{\circ} \mathrm{C}\right)$. The color, flavor, texture, visual fungal growth was observed during the storage period of two months at refrigerated temperature (Table 5). In refrigerated temperature, there was no change in color, flavor and texture change up to 15 days of storage, then slightly changed. There was no fungal growth occurred up to two months for sample $\mathrm{T}_{1}, \mathrm{~T}_{2}$ and $\mathrm{T}_{3}$. Tomato juice treated with Na-benzoate $\left(\mathrm{T}_{2}\right)$ seems to be more stable as after 45 days storage. Tomato juice with KMS $\left(\mathrm{T}_{3}\right)$ was slightly pungent and sediment after 45 days storage and the juice treated with no preservatives was changed after 60 days storage. After two months of storage, color and flavor were slightly changed for $\mathrm{T}_{2}$.

Table 5 Organoleptic evaluation of prepared tomato juice stored at refrigeration temperature

\begin{tabular}{|c|c|c|c|c|c|}
\hline $\begin{array}{l}\text { Storage } \\
\text { period(days) }\end{array}$ & Treatment & Color & Flavor & Texture & Visual fungal growth \\
\hline \multirow{3}{*}{00} & $\mathrm{~T}_{1}$ & Natural & \multirow{3}{*}{$\begin{array}{l}\text { Natural } \\
\text { flavor of Tomato juice }\end{array}$} & \multirow{3}{*}{ Uniform } & \multirow{3}{*}{ No growth } \\
\hline & $\mathrm{T}_{2}$ & Natural & & & \\
\hline & $\mathrm{T}_{3}$ & Natural & & & \\
\hline \multirow{3}{*}{15} & $\mathrm{~T}_{1}$ & No change & No off flavor & Uniform & No growth \\
\hline & $\mathrm{T}_{2}$ & No change & No off flavor & Uniform & No growth \\
\hline & $\mathrm{T}_{3}$ & No change & No off flavor & Uniform & No growth \\
\hline 30 & $\mathrm{~T}_{1}$ & slightly fade & slightly pungent & Uniform & No growth \\
\hline
\end{tabular}




\begin{tabular}{|l|l|l|l|l|l|}
\hline \multirow{3}{*}{45} & $\mathrm{~T}_{2}$ & No change & No off flavor & Uniform & No growth \\
\cline { 2 - 6 } & $\mathrm{T}_{3}$ & No change & No off flavor & Uniform & No growth \\
\hline \multirow{3}{*}{60} & $\mathrm{~T}_{1}$ & Turbid/fade & Slightly pungent & slightly sediment & No growth \\
\cline { 2 - 6 } & $\mathrm{T}_{2}$ & No change & No off flavor & Uniform & No growth \\
\cline { 2 - 6 } & $\mathrm{T}_{3}$ & No change & Slightly pungent & Slightly sediment & No growth \\
\hline & $\mathrm{T}_{1}$ & Turbid/fade & Pungent & sediment & No growth \\
\cline { 2 - 6 } & $\mathrm{T}_{2}$ & Slightly Turbid & Slightly pungent & Slightly sediment & No growth \\
\cline { 2 - 6 } & $\mathrm{T}_{3}$ & Slightly Turbid & Slightly pungent & Slightly sediment & No growth \\
\hline
\end{tabular}

\subsection{Microbial load calculation}

Bacterial Growth: Microbiological activity, its multiplication and load were calculated (Table 6) during 30 days storage period for the juices from three samples. This study was performed by Colony count method and the dextrose tryptone Agar (DTA) media was used. After 48 hour of incubation colonies were counted. The total viable bacteria present in tomato juice were not uniform. Total viable bacterial count of the juice with no preservatives sample $\mathrm{T}_{1}$ increased from 3.77 to $4.51 \log \mathrm{cfu} \mathrm{mL}^{-1}$ after 30 days storage at refrigeration temperature. Total viable bacterial count of the juice with Na-benzoate sample $\mathrm{T}_{2}$ increased from 3.53 to $3.88 \mathrm{log}$ cfu mL $\mathrm{mL}^{-1}$ after 30 days storage at refrigeration temperature. Total viable bacterial count of the juice with KMS sample $\mathrm{T}_{3}$ increased from 3.69 to $4.00 \mathrm{log} \mathrm{cfu} \mathrm{mL}^{-1}$ after 30 days storage at refrigeration temperature. The result showed that among the three sample, sample $\mathrm{T}_{3}$ contained least viable bacteria $(3.88 \mathrm{log} . \mathrm{cfu} / \mathrm{ml})$ and sample $\mathrm{T}_{1}$ contained highest viable bacteria $(4.51 \log \mathrm{cfu} / \mathrm{ml})$ after 30 days at refrigeration temperature. From the above results, it is clear that the total viable bacteria count increased with the increase of storage period. Sample prepared with Nabenzoate $\mathrm{T}_{2}$ contain less viable bacteria compare to other samples. Growth of bacteria in tomato juice at refrigeration temperature is shown in table 6 .

Table 6 Growth of bacteria in tomato juice with three different additives at refrigeration temperature

\begin{tabular}{|c|c|c|c|}
\hline \multirow[t]{2}{*}{ Sample } & Storage period & $\begin{array}{l}\text { No, of total bacteria } \\
\text { (cfu mL-1) }\end{array}$ & Total Count (log cfu ml-1) \\
\hline & Initial & $6 \times 10^{3}$ & 3.77 \\
\hline \multirow[t]{3}{*}{$\mathrm{T}_{1}$ (Control) } & 15 & $1.1 \times 10^{4}$ & 4.04 \\
\hline & 30 & $3.2 \times 10^{4}$ & 4.51 \\
\hline & initial & $3.4 \times 10^{3}$ & 3.53 \\
\hline \multirow[t]{3}{*}{$\mathrm{T}_{2}$ (Na-benzoate) } & 15 & $5.2 \times 10^{3}$ & 3.71 \\
\hline & 30 & $7.6 \times 10^{3}$ & 3.88 \\
\hline & initial & $5 \times 10^{3}$ & 3.69 \\
\hline \multirow[t]{2}{*}{$\mathrm{T}_{3}$ (KMS) } & 15 & $7 \times 10^{3}$ & 3.84 \\
\hline & 30 & $1.5 \times 10^{4}$ & 4.00 \\
\hline
\end{tabular}

\subsection{Sensory evaluation}

A panel of 16 judges (teachers and students of faculty of Agricultural Chemistry) tested the color, flavor, taste and overall acceptability of tomato juice prepared with two preservatives Na-benzoate and KMS. The mean scores for color, flavor, taste and overall acceptability of different treatment of juice such as $\mathrm{T}_{1}, \mathrm{~T}_{2}$ and $\mathrm{T}_{3}$ are presented in Table 7.

Table 7 Mean score for color, flavor and taste and overall acceptability of Tomato juice

\begin{tabular}{|c|c|c|c|c|}
\hline Treatment & Sensory & & & \\
\hline Sample & Color & Flavor & Taste & Overall Acceptability \\
\hline $\begin{array}{l}\mathrm{T}_{1} \\
\text { (Control) }\end{array}$ & $5.1875^{\mathrm{c}}$ & $5.1250^{c}$ & $5.1250^{c}$ & $5.145^{\mathrm{c}}$ \\
\hline $\begin{array}{l}\mathrm{T}_{2} \\
\text { (Na-benzoate) }\end{array}$ & $7.5625^{\mathrm{a}}$ & $7.2500^{\mathrm{a}}$ & $6.8125^{\mathrm{a}}$ & $7.208^{\mathrm{a}}$ \\
\hline $\begin{array}{l}\mathrm{T}_{3} \\
\text { (KMS) }\end{array}$ & $6.3750^{\mathrm{b}}$ & $6.1875^{\mathrm{b}}$ & $5.9375^{b}$ & $6.166^{b}$ \\
\hline LSD $(\mathrm{P}<0.05)$ & 0.5630 & 0.6117 & 0.6109 & 0.4487 \\
\hline CV\% & 12.40 & 13.88 & 14.40 & 10.15 \\
\hline
\end{tabular}

a, b, c superscript indicates respectively the higher, medium and lower value. The test values along the different column carrying different superscripts are significantly different $(\mathrm{p}<0.05)$.

Hedonic scale used: 9 = Like extremely; 8 = Like very much; 7 = Like moderately; 6 = Like slightly; 5 = Neither like nor dislike; 4 = Dislike slightly; 3 = Dislike moderately; 2 = Dislike very much; 1 = Dislike extremely.

Color:

A one way analysis of variance ANOVA (Appendix A.1 and Appendix A.1.1) was carried out forcolor preference and results revealed that there was significant $(\mathrm{P}<0.05)$ difference in color acceptability among the tomato juice. The results of DMRT (Appendix A.1.2) showed that there was significant difference for color difference among the three samples $\mathrm{T}_{1}, \mathrm{~T}_{2}$ and $\mathrm{T}_{3}$ (Table 7). In case of color preference among the treatment, the treatment $\mathrm{T}_{2}$ was more acceptable than treatment $\mathrm{T}_{1}$ and $\mathrm{T}_{3}$. Treatment $\mathrm{T}_{2}$ secured the highest score 7.5625 and ranked as "Like very much". Treatment $\mathrm{T}_{1}$ ranked as "Neither like nor dislike" and $\mathrm{T}_{3}$ are ranked as "Like slightly" securing score 5.1875 and 5.9375 , respectively.

\section{Flavor:}

A one way analysis of variance ANOVA (Appendix A.2 and Appendix A.2.1) was carried out forflavor preference and results revealed that there was significant $(\mathrm{P}<0.05)$ difference in color acceptability among the tomato juice. The results of DMRT (Appendix A.2.2) showed that there was significant difference for flavor difference among the three samples $T_{1}, T_{2}$ and $T_{3}$ (Table 7). In case of flavor preference among the treatment, the treatment $T_{2}$ was more 
acceptable than treatment $\mathrm{T}_{1}$ and $\mathrm{T}_{3}$. Treatment $\mathrm{T}_{2}$ secured the highest score 7.2500 and ranked as "Like moderately". Treatment $\mathrm{T}_{1}$ ranked as "Neither like nor dislike" and $\mathrm{T}_{3}$ are ranked as "like slightly" securing score 5.1250 and 6.1875 , respectively.

\section{Taste:}

A one way analysis of variance ANOVA (Appendix A.3 and Appendix A.3.1) was carried out fortaste preference and results revealed that there was significant $(\mathrm{P}<0.05)$ difference in taste acceptability among the tomato juice. The results of DMRT (Appendix A.3.2) showed that there was significant difference for taste difference among the three samples $\mathrm{T}_{1}, \mathrm{~T}_{2}$ and $\mathrm{T}_{3}$ (Table 7). In case of taste preference among the treatment, the treatment $\mathrm{T}_{2}$ was more acceptable than treatment $\mathrm{T}_{1}$ and $\mathrm{T}_{3}$. Treatment $\mathrm{T}_{2}$ secured the highest score 6.8125 and ranked as "Like moderately". Treatment $\mathrm{T}_{1}$ ranked as "Neither like nor dislike" and $\mathrm{T}_{3}$ are ranked as "like slightly" securing score 5.1250 and 5.9375 , respectively.

\section{Overall Acceptability:}

It was apparent from the results of the ANOVA (Appendix A.4 and Appendix A.4.1), that there was significant ( $<<0.05$ ) difference in overall acceptability of the treatment tested as the calculated F (47.304) greater than the tabulated F value (2.960). This indicates that so far as overall acceptability is concern the treatments were not equally acceptable. Significant difference exist when $\mathrm{F}$ (Calculated) $>\mathrm{F}$ (Tabulated). It can be seen from Table 7 that the treatment $\mathrm{T}_{2}$ is the most acceptable product receiving 7.208 out of 9.0 compared to the other treatment and ranked as "Like moderately". Treatment $\mathrm{T}_{3}$ securing 6.166 ranked as "like slightly ". However T1securing 5.145 ranked as "Neither like nor dislike ".

Tomato juice $\mathrm{T}_{2}$ containing Na-benzoate preservative secured the highest score for color, flavor, taste and overall acceptability among all the treatment and was closely followed by fruit juice $\mathrm{T}_{3}$ having KMS preservatives after 30days storage. So, treatment $\mathrm{T}_{2}$ tomato juice may be regarded as the best juice among the four treatments.

\subsection{Summary and Conclusion}

To assess the physic-chemical properties and the effect of chemical preservatives on the shelf life of prepared tomato juice, three treatments namely, $\mathrm{T}_{1}, \mathrm{~T}_{2}$ and $\mathrm{T}_{3}$ were considered for study prepared with $60 \%$ tomato juice, $40 \%$ water, $20 \%$ sugar and $300 \mathrm{ppm}$ sodium benzoate and KMS preservatives. Sample $\mathrm{T}_{1}, \mathrm{~T}_{2}$ and $\mathrm{T}_{3}$ was prepared with no preservatives, Na-benzoate, KMS respectively. The shelf life and consumer`s acceptability of the prepared mixed juice were studied. The juice was stored at refrigerated temperature $\left(4^{\circ} \mathrm{C}\right)$ for two months.

The physical and chemical analysis (Moisture, TSS, acidity, pH, vitamin C, Protein, Total sugar, mineral content such as potassium (K), calcium (Ca), magnesium (Mg) of the prepared tomato juice for treatment $\mathrm{T}_{1}, \mathrm{~T}_{2}, \mathrm{~T}_{3}$ were done immediate after preparation i.e. $0^{\text {th }}$ day. The effect of chemical preservatives on Moisture, TSS, acidity, $\mathrm{pH}$, vitamin $\mathrm{C}$ were found at an interval $0,15,30$ days storage period. On the day of preparation the Treatment $\mathbf{T}_{1}$ contained Moisture 81.28\%, pH 4.693, TSS $13.13 \%$,acidity $0.2480 \%$, vitamin C $12.25 \mathrm{mg} / 100 \mathrm{~g}$, total sugar $6.44 \%$. Treatment $\mathbf{T}_{2}$ contained Moisture $83.15 \%$, pH 4.677, TSS $13.46 \%$,acidity $0.3117 \%$, vitamin C $15.62 \mathrm{mg} / 100 \mathrm{~g}$, total sugar $8.06 \%$. Treatment $\mathbf{T}_{3}$ contained Moisture $83.22 \%$, pH 4.687, TSS $13.22 \%$,acidity $0.2553 \%$, vitamin C $15.75 \mathrm{mg} / 100 \mathrm{~g}$, total sugar $9.66 \%$. After 30 days storage the Treatment $\mathbf{T}_{1}$ contained Moisture $81.26 \%$, pH 4.443, TSS $12.16 \%$, acidity $0.2730 \%$, vitamin C $2.26 \mathrm{mg} / 100$ g. Treatment $\mathbf{T}_{2}$ contained Moisture 81.16\%, pH 4.357, TSS 13.05\%, acidity $0.3147 \%$, vitamin C $11.25 \mathrm{mg} / 100 \mathrm{~g}$. Treatment $\mathrm{T}_{3}$ contained Moisture 83.21\%, pH 4.273, TSS $12.62 \%$, acidity $0.3117 \%$, vitamin C $5.033 \mathrm{mg} / 100 \mathrm{~g}$. Negligible Change in physical and chemical constituents except vitamin $\mathrm{C}$ was observed in the prepared juice throughout the 30 days storage period.The statistical analysis of the score response by the taste-testing panelists on the sensory attributes of juice revealed that color, flavor, taste and overall acceptability of the differently treated juice were significantly $(\mathrm{p}<0.05)$ different. It was found that color, flavor, taste and overall acceptability of tomato juice of treatment $\mathrm{T}_{2}$ (tomato juice prepared with Na-benzoate) was more acceptable than other treatments.

Immediately after preparation of juice, total number of viable count was not uniform. It also showed that after 30 days intervals revealed that total colony increased slightly with the increase of storage period. After 30 days storage, number of total bacteria was less in tomato juice treated with Na-benzoate compare to other treatments. After 60 days sedimentation problem occurs in the samples. This may be due to improper capping, coarse homogenization etc. The study demonstrated that the tomato juice was effective to maintain the edible quality during two months of storage at refrigerated temperature $\left(4^{\circ} \mathrm{C}\right)$. Use of preservatives (Na-benzoate) was also effective against microbial growth to prevent spoilage.

The experimental finding concludes that, it is possible to prepare tomato juice in Bangladesh those cannot be preserved for long time. The tomato juice with a simple preservatives sodium benzoate and packed in glass bottles manually can be easily preserved for two months in refrigerated temperature without any spoilage and less taste, color and flavor. Every year in Bangladesh a large amount of tomatoes are damaged due to inadequate processing and preservation facilities. The juice preparation is a simple technique for preservation and suitable for cottage and small scale enterprises.

\section{References}

[1] M.T. Ahmed, “Residues of methomyl on strawberries, tomatoes and cucumber”, Pesticide Science,197-199, 1995.

[2] V.O. Ajibola, O.A. Babatunde, and S. Suleiman, "Effects of storage methods on the vitamin C content of some tropical fruit juices", Trends Appl. Sci. Res., Vol. 4(2), 79-84, 2009.

[3] S.A. Akinola, M.F. Ogundipe, and O.F. Osundahunsi, "Ginger Inclusion Influences the Antioxidant Properties, Physico-Chemical and Microbiological Quality of Orange-Watermelon-Carrot Juice. In: Translating Research Findings into Policy in Developing Countries-Contributions”, Humboldt KollegOsogbo. 241-260, 2017.

[4] M.O. Akusu, B.D. Kiin-Kabari, and O.C. Ebere, "Quality Characteristics of Orange/Pineapple/tomato Juice Blends", Am. J. Food Science and Technology, Vol. 4(2), 43-47, 2016.

[5] M.A. Ali, "Recommended method for the microbiological examination of food", 78-79, 2008.

[6] AOAC, "Official method of Analysis of the Association of official Analytical chemists",15th ed, Washington. USA, 2004.

[7] M. Ayub, and M.B. Khan, "Effect of different light conditions and colored glass bottles on the retention of quality characteristics of pomegranate syrup during storage at room temperature”, Sarhad J. Agr., Vol. 17(4), 629-632, 2001.

[8] L.A. Bazzano, M.K. Serdula, and S. Liu, “Dietary intakes of F\&V and risk of cardiovascular disease”, Vol. 5, 492-499, 2002.

[9] R.L. Bhardwaj, and S. Mukherjee, "Effects of fruit juice blending ratios on kinnow juice preservation at ambient storage condition", Afri. J. Food Science, Vol. 5(5), 281-286, 2011. 
[10] M.M. Deanna, and S.B. Jeffrey, “Acid-alkaline Balance: Role in Chronic Disease and Detoxification”, Alternative therapy”, Vol. 13(4), 62-65, 2007.

[11] B.C. Deka, and V. Sethi, "Preparation of mixed fruit juice spiced RTS beverages”, Vol. 42(3), 58-61, 2001.

[12] A. El-Sheikha, M. Zaki, A. Bakr, M. El-Habashy, and D. Montet, "Biochemical and sensory quality of physalis (Physalispubescens I.) juice”, J. Food Processing and Preservation, Vol. 34, 541-555, 2010.

[13] A.H. Ensminger, M.E. Ensminger, J.E. Konlabde, and J.R.K. Robson, “Food \& Nutrition Encyclopedia”, 1'sted, 1, 966, 1983.

[14] W.C. Frazier, and D.C. Westhoff, "Food Microbiology.Tata McGraw-Hill Co. Ltd", 4th ed, 83-98, 1995.

[15] C.B. Heiser, and Nightshades: “The Paradoxical Plants”, San Francisco: W. H. Freeman, 200, 1969.

[16] S.M. Herna'́ndez, E.R. Rodrı'guez, and C. Díaz Romero, "Analysis of organic acid content in cultivars of tomato harvested in Tenerife", European Food Research and Technology, 2007.

[17] M.N. Hossain, M. Fakruddin, and M.N. Islam, “Effect of chemical additives on the shelf life of tomato juice”, Am.J. Food Technology, Vol. 6(10), 914-923, 2011.

[18] I. Hussain, A. Zeb, and M. Ayub, "Evaluation of apple and apricot blend juice preserved with sodium benzoate at refrigeration temperature", World J. Dairy Food Sci., Vol. 6, 79-85, 2011.

[19] R. Ilahy, C. Hdider, M.S. Lenucci, and G.I. Tlili, and Dalessandro, "Phytochemical composition and antioxidant activity of high-lycopene tomato (SolanumlycopersicumL.) cultivars grown in Southern Italy", Scientia Horticulturae, Vol. 127, 255-261, 2011.

[20] S. Jannat, M.Y. Ali, H.R. Kim, H.A. Jung, and J.S. Choi, "Protective Effects of Sweet Orange, Unshiu Mikan, and Mini Tomato Juice Powders on $t$-BHPInduced Oxidative Stress in HepG2 Cells", Prev Nutr Food Sci. Sep, Vol. 21(3), 208-220, 2016.

[21] P. Juroszek, H.M. Lumpkin, R.Y. Yang, D.R. Ledesma, and C.H. Ma, “Fruit quality and bioactive compounds with antioxidant activity of tomatoes grown on-farm: comparison of organic and conventional management systems", J. Agric. Food Chem., Vol. 57, 1188-1194, 2009.

[22] G. Kaur, and P. Aggarwal, "Storage Studies on Bitter Gourd Juice Preserved with Different Chemical Preservatives", J. of Res. Eng. and Technol., Vol. $3(1), 223-227,2014$.

[23] Z. Kotkov, J. Lachman, A. Hejtmnkov, and K. Hejtmnkov, "Determination ofantioxidant activity and antioxidant content in tomato varieties and evaluation ofmutual interactions between antioxidants.LWT", Food Sci. \& Technol. Vol. 44: 1703-1710, 2011.

[24] B.W. Li, K.W. Andrews, and P.R. Pehrsson, "Individual sugars, soluble and insoluble dietary fiber contents of 70 high consumption foods", J. Food Composition and Analysis, Vol. 15, 715-723, 2002.

[25] R. Mahmud, N. Islam, A.K.M.S. Inan, and D.C. Roy, "Studies of the verities effect on the prepared tomato juice”, Bangladesh Res, Pub. J., Vol. 3, 787-795, 2009.

[26] 0.M. Makanjuola, A.O. Adepegba, A. Ajayi, and J.O. Makanjuola, "Effect of different preservation methods on the quality attributes of some tropical fruit juices", Adv. Biores., Vol. 4(4), 74-78, 2013.

[27] J. Ndife, D. Awogbenja, and U. Zakari, "Comparative evaluation of the nutritional and sensory quality of different brands of orange-juice in Nigerian market”, Afri. J. Food Science, Vol. 7(12), 479-484, 2013.

[28] X.N. Ng, F.Y. Chye, and M.A. Ismail, "Nutritional profile and antioxidative properties of selected tropical wild vegetables", J. International Food Research, Vol. 19(4), 1487-1496, 2012.

[29] E. Nwachukwu, and F.C. Ezejiaku, "Microbial and physicochemical characteristics of locally produced pineapple juice treated with garlic and ginger", Inter. J.Curr. Microbiol. and Appl. Sci., Vol. 3(6), 895-901, 2014.

[30] D. Pearson, "The Chemical Analysis of Foods. Churchill Living stone", (7th ed). Edinburgh London: 16-18, 1976.

[31] S.M.M. Rahman, and M.A. Hossain, “Total phenolics, flavonoids and antioxidant activity of tropical fruit pineapple”, Food Research International. Vol. $44,672-676,2011$.

[32] S. Rangana, "Manual of Analysis of Fruits and Vegetable Products", Tata McGraw-Hill Co. Ltd. New Delhi: 2-95,634, 1977.

[33] M. Shahnawaz, S.A. Sheikh, and S. Minhas, "Role of sodium benzoate as a chemical preservative in extending the shelf life of orange juice", Global Adv Res. J. Food Sci. Technol, Vol. 2(1), 7-18, 2013.

[34] V.P. Van't, M. Jansen, M. Klerk, and F.J. Kok, “Fruits and vegetables in the prevention of cancer and cardiovascular disease”, Public Health Nutr., Vol. 3 , 103-107, 2002.

[35] D.D. Wadikar, T.K. Majumdar, and A.S. Bawa, “Development, stability and sensory acceptability of cucumber-basil juice blend”, Afri. J. Food. Agric. Nutr and Dev, Vol. 10, 4093-4104, 2010.

[36] B.K. Watt, and A.L. Merrill, "Composition of food. Agricultural Handbook”, (No.8). USDA: Washington, DC, 1963.

[37] A. Zeb, I.A. Khalil, and M. Ayub, “Grape juice preservation with benzoate and sorbate”, J. Advances in Food Sci, Vol. 31(1), 17-21, 2009.

\section{Appendices}

Table A.1: Rating score for color of Tomato juice

\begin{tabular}{|l|l|l|l|}
\hline No. of Panelists & Sample T1 & Sample T2 & Sample T3 \\
\hline 1 & 7 & 8 & 7 \\
\hline 2 & 7 & 7 & 8 \\
\hline 3 & 6 & 7 & 6 \\
\hline 4 & 5 & 7 & 6 \\
\hline 5 & 5 & 8 & 7 \\
\hline 6 & 4 & 8 & 7 \\
\hline 7 & 5 & 8 & 7 \\
\hline
\end{tabular}




\begin{tabular}{|l|l|l|l|}
\hline 8 & 4 & 8 & 7 \\
\hline 9 & 5 & 7 & 6 \\
\hline 10 & 5 & 8 & 6 \\
\hline 11 & 5 & 8 & 6 \\
\hline 12 & 6 & 8 & 6 \\
\hline 13 & 6 & 8 & 7 \\
\hline 14 & 4 & 7 & 5 \\
\hline 15 & 5 & 7 & 5 \\
\hline 16 & 4 & 7 & 6 \\
\hline Total & 83 & 121 & 102 \\
\hline Mean & 5.1875 & 7.5625 & 6.375 \\
\hline
\end{tabular}

Hedonic scale used: 9 = like extremely; $8=$ like very much; 7 = like moderately; $6=$ like slightly; $5=$ neither like nor dislike; $4=$ dislike slightly; $3=$ dislike moderately; 2 = dislike very much; 1 = dislike extremely.

Table A.1.1: ANOVA (Analysis of variance) for color of tomato juice

\begin{tabular}{|l|l|l|l|l|l|l|}
\hline \multicolumn{2}{|c|}{} & Sum of Squares & df & Mean Square & F & Sig. \\
\hline \multirow{4}{*}{ Color } & Between Groups & 45.125 & 2 & 22.563 & 36.100 & .000 \\
\cline { 2 - 8 } & Within Groups & 28.125 & 45 & .625 & & \\
\cline { 2 - 8 } & Total & 73.250 & 47 & & & \\
\hline
\end{tabular}

Table A.1.2: DMRT (Duncan's Multiple Range test) test for color of tomato juice

\begin{tabular}{|c|c|c|c|c|}
\hline \multicolumn{5}{|l|}{\begin{tabular}{|l|} 
Color \\
\end{tabular}} \\
\hline \multicolumn{5}{|l|}{ Duncana } \\
\hline \multirow[b]{2}{*}{ Sample } & \multirow[b]{2}{*}{$\mathrm{N}$} & \multicolumn{3}{|c|}{ Subset for alpha $=0.05$} \\
\hline & & 1 & 2 & 3 \\
\hline \begin{tabular}{|l|} 
Sample 1 \\
\end{tabular} & 16 & 5.1875 & & \\
\hline Sample 3 & 16 & & 6.3750 & \\
\hline \begin{tabular}{|l|} 
Sample 2 \\
\end{tabular} & 16 & & & 7.5625 \\
\hline \begin{tabular}{|l|} 
Sig. \\
\end{tabular} & & \begin{tabular}{|l|}
1.000 \\
\end{tabular} & $\begin{array}{l}1.000 \\
\end{array}$ & 1.000 \\
\hline
\end{tabular}

Table A.1.3: Duncan's Multiple Range Test (DMRT) for color $L S D$ value $=0.5630, \mathrm{P}<0.05$

\begin{tabular}{|l|l|l|l|}
\hline Treatment code & Original order of means & Treatment Code & Ranked order of means \\
\hline $\mathrm{T}_{1}$ & $5.1875^{\mathrm{c}}$ & $\mathrm{T}_{2}$ & $7.5625^{\mathrm{a}}$ \\
\hline $\mathrm{T}_{2}$ & $7.5625^{\mathrm{a}}$ & $\mathrm{T}_{3}$ & $6.3750^{\mathrm{b}}$ \\
\hline $\mathrm{T}_{3}$ & $6.3750^{\mathrm{b}}$ & $\mathrm{T}_{1}$ & $5.1875^{\mathrm{c}}$ \\
\hline
\end{tabular}

Table A.2: Rating score for flavor of Tomato juice

\begin{tabular}{|l|l|l|l|}
\hline No. of Panelists & Sample T1 & Sample T2 & Sample T3 \\
\hline 1 & 6 & 8 & 6 \\
\hline 2 & 6 & 8 & 7 \\
\hline 3 & 5 & 8 & 7 \\
\hline 4 & 6 & 8 & 7 \\
\hline 5 & 5 & 7 & 7 \\
\hline 6 & 7 & 7 & 7 \\
\hline 7 & 3 & 8 & 6 \\
\hline 8 & 4 & 8 & 5 \\
\hline 9 & 6 & 8 & 7 \\
\hline 10 & 5 & 7 & 4 \\
\hline 11 & 5 & 7 & 6 \\
\hline 12 & 5 & 7 & 6 \\
\hline 13 & 5 & 7 & 6 \\
\hline 14 & 5 & 6 & 6 \\
\hline 15 & 4 & 6 & 6 \\
\hline 16 & 5 & 6 & 6 \\
\hline Total & 82 & 116 & 99 \\
\hline Mean & 5.125 & 7.25 & 6.1875 \\
\hline
\end{tabular}

Hedonic scale used: 9 = like extremely; 8 = like very much; 7 = like moderately; 6 = like slightly; 5 = neither like nor dislike; 4 = dislike slightly; 3 = dislike moderately; 2 = dislike very much; 1 = dislike extremely.

Table A.2.1: ANOVA (Analysis of variance) for flavor of tomato juice

\begin{tabular}{|l|l|l|l|l|l|l|}
\hline \multicolumn{2}{|c|}{} & Sum of Squares & df & Mean Square & F & Sig. \\
\hline Flavor & Between Groups & 36.125 & 2 & 18.063 & 24.492 & .000 \\
\cline { 2 - 8 } & Within Groups & 33.188 & 45 & .738 & & \\
\cline { 2 - 8 } & Total & 69.313 & 47 & & & \\
\hline
\end{tabular}


Table A.2.2: DMRT (Duncan's Multiple Range test) test for flavor of tomato juice

\section{Flavor}

Duncan $^{\mathrm{a}}$

\begin{tabular}{|c|c|c|c|c|}
\hline \multirow[b]{2}{*}{ Sample } & \multirow[b]{2}{*}{$\mathrm{N}$} & \multicolumn{3}{|c|}{ Subset for alpha $=0.05$} \\
\hline & & 1 & 2 & 3 \\
\hline Sample 1 & 16 & 5.1250 & & \\
\hline Sample 3 & 16 & & 6.1875 & \\
\hline Sample 2 & 16 & & & 7.2500 \\
\hline Sig. & & 1.000 & 1.000 & 1.000 \\
\hline
\end{tabular}

Table A.2.3: Duncan's Multiple Range Test (DMRT) for flavor $L S D$ value $=0.6117, \mathrm{P}<0.05$

\begin{tabular}{|l|l|l|l|}
\hline Treatment code & Original order of means & Treatment Code & Ranked order of means \\
\hline $\mathrm{T}_{1}$ & $5.1250^{\mathrm{c}}$ & $\mathrm{T}_{2}$ & $7.250^{\mathrm{a}}$ \\
\hline $\mathrm{T}_{2}$ & $7.2500^{\mathrm{a}}$ & $\mathrm{T}_{3}$ & $6.1875^{\mathrm{b}}$ \\
\hline $\mathrm{T}_{3}$ & $6.1875^{\mathrm{b}}$ & $\mathrm{T}_{1}$ & $5.1250^{\mathrm{c}}$ \\
\hline
\end{tabular}

Table A.3: Rating score for taste of Tomato juice

\begin{tabular}{|l|l|l|l|}
\hline No. of Panelists & Sample T1 & Sample T2 & Sample T3 \\
\hline 1 & 6 & 7 & 7 \\
\hline 2 & 6 & 8 & 7 \\
\hline 3 & 5 & 6 & 7 \\
\hline 4 & 6 & 7 & 8 \\
\hline 5 & 6 & 6 & 6 \\
\hline 6 & 7 & 7 & 7 \\
\hline 7 & 4 & 7 & 5 \\
\hline 8 & 4 & 7 & 5 \\
\hline 9 & 4 & 7 & 5 \\
\hline 10 & 5 & 7 & 6 \\
\hline 11 & 4 & 7 & 5 \\
\hline 12 & 6 & 7 & 6 \\
\hline 13 & 4 & 6 & 5 \\
\hline 14 & 5 & 6 & 5 \\
\hline 15 & 5 & 7 & 6 \\
\hline 16 & 5 & 7 & 5 \\
\hline Total & 82 & 109 & 95 \\
\hline Mean & 5.125 & 6.8125 & 5.9375 \\
\hline
\end{tabular}

Hedonic scale used: 9 = like extremely; $8=$ like very much; 7 = like moderately; $6=$ like slightly; $5=$ neither like nor dislike; $4=$ dislike slightly; $3=$ dislike moderately; 2 = dislike very much; 1 = dislike extremely.

Table A.3.1: ANOVA (Analysis of variance) for taste of tomato juice

\begin{tabular}{|c|c|c|c|c|c|c|}
\hline & & Sum of Squares & $\mathrm{df}$ & Mean Square & F & Sig. \\
\hline \multirow[t]{3}{*}{ Taste } & Between Groups & 22.792 & 2 & 11.396 & 15.481 & .000 \\
\hline & Within Groups & 33.125 & 45 & \begin{tabular}{|l|}
.736 \\
\end{tabular} & & \\
\hline & Total & 55.917 & 47 & & & \\
\hline
\end{tabular}

Table A.3.2: DMRT (Duncan's Multiple Range test) test for taste of tomato juice

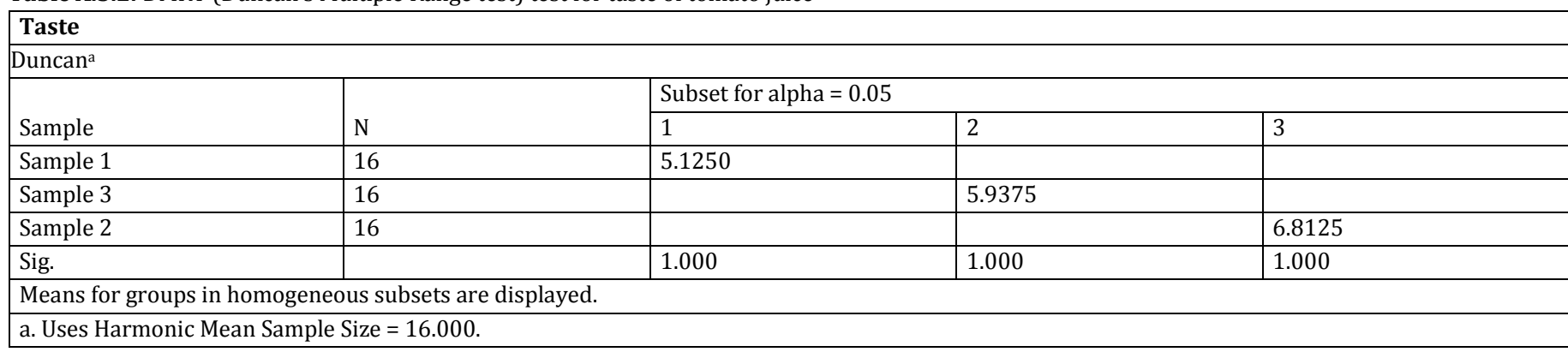

Table A.3.3: Duncan's Multiple Range Test (DMRT) for taste $\mathrm{LSD}$ value $=0.6109, \mathrm{P}<0.05$

\begin{tabular}{|l|l|l|l|}
\hline Treatment code & Original order of means & Treatment Code & Ranked order of means \\
\hline $\mathrm{T}_{1}$ & $5.1250^{\mathrm{c}}$ & $\mathrm{T}_{2}$ & $6.8125^{\mathrm{a}}$ \\
\hline $\mathrm{T}_{2}$ & $6.8125^{\mathrm{a}}$ & $\mathrm{T}_{3}$ & $5.9375^{\mathrm{b}}$ \\
\hline $\mathrm{T}_{3}$ & $5.9375^{\mathrm{b}}$ & $\mathrm{T}_{1}$ & $5.1250^{\mathrm{c}}$ \\
\hline
\end{tabular}

Table A.4: Rating score for overall acceptability of Tomato juice 


\begin{tabular}{|l|l|l|l|}
\hline No. of Panelists & Sample T1 & Sample T2 & Sample T3 \\
\hline 1 & 6 & 8 & 7 \\
\hline 2 & 6 & 8 & 7 \\
\hline 3 & 5 & 7 & 7 \\
\hline 4 & 6 & 7 & 7 \\
\hline 5 & 5 & 7 & 7 \\
\hline 6 & 6 & 7 & 7 \\
\hline 7 & 4 & 8 & 6 \\
\hline 8 & 4 & 8 & 6 \\
\hline 9 & 5 & 7 & 6 \\
\hline 10 & 5 & 7 & 5 \\
\hline 11 & 5 & 7 & 6 \\
\hline 12 & 6 & 7 & 6 \\
\hline 13 & 5 & 7 & 6 \\
\hline 14 & 5 & 6 & 5 \\
\hline 15 & 5 & 7 & 6 \\
\hline 16 & 5 & 7 & 6 \\
\hline Total & 83 & 115 & 100 \\
\hline Mean & 5.1875 & 7.1875 & 6.25 \\
\hline
\end{tabular}

Hedonic scale used: 9 = like extremely; 8 = like very much; 7 = like moderately; 6 = like slightly; $5=$ neither like nor dislike; $4=$ dislike slightly; $3=$ dislike moderately; 2 = dislike very much; 1 = dislike extremely.

Table A.4.1: ANOVA (Analysis of variance) for overall acceptability of tomato juice

\begin{tabular}{|l|l|l|l|l|l|l|}
\hline \multicolumn{2}{|c|}{} & Sum of Squares & df & Mean Square & F & Sig. \\
\hline \multirow{2}{*}{$\begin{array}{l}\text { Overall } \\
\text { acceptability }\end{array}$} & Between Groups & 34.032 & 2 & 17.016 & 47.304 & .000 \\
\cline { 2 - 8 } & Within Groups & 16.187 & 45 & .360 & & \\
\cline { 2 - 8 } & Total & 50.220 & 47 & & & \\
\hline
\end{tabular}

Table A.4.2: DMRT (Duncan's Multiple Range test) test for overall acceptability of tomato juice

\section{Overall_acceptability}

\section{Duncan $^{\mathrm{a}}$}

\begin{tabular}{|c|c|c|c|c|}
\hline \multirow[b]{2}{*}{ Sample } & \multirow[b]{2}{*}{$\mathrm{N}$} & \multicolumn{3}{|c|}{ Subset for alpha $=0.05$} \\
\hline & & 1 & 2 & 3 \\
\hline Sample 1 & 16 & 5.1458 & & \\
\hline \begin{tabular}{|l|} 
Sample 3 \\
\end{tabular} & 16 & & 6.1667 & \\
\hline Sample 2 & 16 & & & 7.2083 \\
\hline Sig. & & 1.000 & 1.000 & 1.000 \\
\hline
\end{tabular}

Table A.4.3: Duncan's Multiple Range Test (DMRT) for overall acceptability LSD value $=0.4487, \mathrm{P}<0.05$

\begin{tabular}{|l|l|l|l|}
\hline Treatment code & Original order of means & Treatment Code & Ranked order of means \\
\hline $\mathrm{T}_{1}$ & $5.1458^{\mathrm{c}}$ & $\mathrm{T}_{2}$ & $7.2083^{\mathrm{a}}$ \\
\hline $\mathrm{T}_{2}$ & $7.2083^{\mathrm{a}}$ & $\mathrm{T}_{3}$ & $6.1667^{\mathrm{b}}$ \\
\hline $\mathrm{T}_{3}$ & $6.1667^{\mathrm{b}}$ & $\mathrm{T}_{1}$ & $5.1458^{\mathrm{c}}$ \\
\hline
\end{tabular}

Table A.5: Testing for Tomato Juice

Name of Taster: ....................................

Date:

Please test these samples and check how much you like or dislike each one on four sensory attributes such as Color, Flavor, Texture and Taste. Use the appropriate scale to show your attitude by checking at the point that best describes your feeling about the sample. Please give a reason for this attitude. Remember you are the only one who can tell what you like. An honest expression of your personal feeling will help me.

\begin{tabular}{|l|l|l|l|l|}
\hline Sample ID & Color & Flavor & Taste & Overall acceptability \\
\hline Sample T1 & & & & \\
\hline Sample T2 & & & & \\
\hline Sample T3 & & & & \\
\hline
\end{tabular}

Extra comments on each sample if any:

N.B. Overall Evaluation:

Hedonic scale used: 9 = like extremely; 8 = like very much; 7 = like moderately; 6 = like slightly; 5 = neither like nor dislike; $4=$ dislike slightly; $3=$ dislike moderately; 2 = dislike very much; 1 = dislike extremely. 